\title{
PENGARUH PENGEMBANGAN SUMBER DAYA MANUSIA TERHADAP PENINGKATAN PRESTASI KERJA PEGAWAI PADA DINAS PEKERJAAN UMUM DAN PERUMAHAN RAKYAT KABUPATEN LAMPUNG BARAT
}

\author{
Sahrun $^{(1)}$, Fahrizi ${ }^{(2)}$, Khairul Saleh ${ }^{(3)}$ \\ Fakultas Ekonomi Universitas Sang Bumi Ruwa Jurai \\ sahrun78@gmail.com,fahrizi@fe.saburai.ac.id, khairul.saleh@fe.saburai.ac.id
}

\begin{abstract}
Abstrak. Pembinaan dan pengembangan di lingkup pegawai diharapkan akan memberi efek pengembangan prestasi kerja yang dimiliki oleh seorang pegawai, dalam hal ini Dinas Pekerjaan Umum Dan Perumahan yang mempunyai tugas utama sebagai pelayanan masyarakat dibidang infrastruktur maka pegawai yang ada harus melakukan pengembangan sumber daya manusia yang untuk meraih prestasi kerja yang terbaik. Tujuan dari penelitian ini untuk mengetahui pengaruh pengembangan sumber daya manusia terhadap peningkatan prestasi kerja pegawai Dinas Pekerjaan Umum dan Perumahan Rakyat Kabupaten Lampung Barat. Hipotesis penelitian dinyatakan "terdapat pengaruh pengembangan sumber daya manusia terhadap peningkatan prestasi kerja pegawai Dinas Pekerjaan Umum dan Perumahan Rakyat Kabupaten Lampung Barat". Pengumpulan data penelitian menggunakan teknik sampel penelitian dari 40 responden. Pengembangan sumber daya manusia $(\mathrm{X})$ berpengaruh positif dan signifikan terhadap prestasi kerja pegawai (Y). Hal ini dibuktikan dengan nilai $t_{\text {hitung }}=2,520(\mathrm{X})$ yang lebih besar dari nilai tabel $=1,717$, serta nilai signifikansi P (Sig) 0,019 lebih kecil dari $\alpha=0,05$, sehingga hipotesis Ho ditolak dan $\mathrm{H}_{1}$ diterima.
\end{abstract}

Kata kunci: Kinerja, Pengembangan, Prestasi, SDM.

\section{PENDAHULUAN}

Keberadaan sumber daya manusia dalam suatu organisasi merupakan aset yang berharga bagi organisasi itu sendiri. Keberhasilan suatu organisasi ditentukan dari kualitas orang-orang yang berada di dalamnya. sumber daya manusia akan bekerja secara optimal jika organisasi dapat mendukung kemajuan karir mereka dengan melihat apa sebenarnya kompetensi mereka. Biasanya, pengembangan sumber daya manusia akan mempertinggi prestasi kerja pegawai sehingga kualitas kerja pun lebih tinggi pula dan berujung pada puasnya masyarakat sebagai penerima manfaat.

Sumber daya manusia atau biasa disingkat menjadi SDM merupakan potensi yang terkandung dalam diri manusia untuk mewujudkan perannya sebagai makhluk sosial yang adaptif dan transformatif yang mampu mengelola dirinya sendiri serta seluruh potensi yang terkandung di alam menuju tercapainya kesejahteraan kehidupan dalam tatanan yang seimbang dan berkelanjutan. Dalam pengertian praktis sehari-hari, SDM lebih dimengerti sebagai bagian integral dari sistem yang membentuk suatu organisasi.

Melihat pentingnya sumber daya manusia dalam suatu organisasi atau instansi, maka tidak berlebihan jika dikatakan bahwa manusia adalah aset yang paling penting dan berdampak langsung pada organisasi atau instansi tersebut dibandingkan dengan sumber daya-sumber daya lainnya. Karena manusia memberikan tenaga, bakat, kreativitas, dan usaha mereka kepada organisasi atau instansi tersebut . Untuk menjawab tantangan tersebut, pemerintah harus memiliki sumber daya manusia dalam hal ini Pegawai yang berkualitas dan professional. Pembinaan, pengembangan dan peningkatan kualitas 
dan profesionalitas Pegawai menjadi salah satu upaya yang tepat untuk menghadapi dan merespons segala tantangan yang berkaitan dengan perubahan tersebut. Oleh karena itu, pegawai sebagai aparatur pemerintah, abdi negara dan abdi masyarakat perlu terus ditingkatkan kualitas dan profesionalitasnya secara terarah, terprogram dan berkelanjutan, sehingga diharapkan penyelenggaraan pemerintahan dan pembangunan dapat berjalan secara optimal.

Dengan demikian pembinaan pegawai secara individual merupakan upaya untuk menciptakan efektivitas prestasi kerja pegawai, melalui peningkatan keterampilan dan kemampuan kerja, memotivasi untuk meningkatkan dedikasi dan pengabdian, memperbaikai dan memelihara sikap mental, etos kerja dan integritas.

Pembinaan dan pengembangan di lingkup pegawai diharapkan akan memberi efek pengembangan prestasi kerja yang dimiliki oleh seorang pegawai,dalam pencapaian prestasi kerja seorang pegawai tidak terlepas dari kemampuannya menguasai sistem yang ada di organisasi tersebut, dalam hal ini Dinas Pekerjaan Umum Dan Perumahan Rakyat Kabupaten Lampung Barat yang mempunyai tugas utama sebagai pelayanan maka pegawai yang ada harus menguasai tugasnya yang terdapat di lingkup Dinas Pekerjaan Umum Dan Perumahan Rakyat Kabupaten Lampung Barat untuk meraih prestasi kerja yang terbaik.

Permasalahan yang ditemukan di Dinas Pekerjaan Umum dan Perumahan Rakyat Kabupaten Lampung Barat antara lain pengembangan sumber daya manusia yang dilakukan pimpinan belum memberikan dampak peningkatan prestasi kerja pegawai. Hal tersebut dapat dilihat dari target kerja yang sering tidak tercapai, tertundanya pekerjaan dan tidak berkembangnya kemampuan bawahan, Hal tersebut dapat dilihat dari ketertinggalan pegawai dalam penguasaan teknologi yang berkaitan dengan pekerjaan. Kemudian prestasi kerja pegawai relatif tidak sesuai harapan pimpinan, umumnya pegawai hanya melaksanakan tugas sebatas rutinitas saja tanpa ada dorongan untuk mencapai prestasi kerja sebaik mungkin.

Berdasarkan fenomena tersebut, maka penulis tertarik untuk meneliti lebih lanjut dengan judul: "Pengaruh Pengembangan sumber daya manusia Terhadap Peningkatan Prestasi kerja Pegawai Dinas Pekerjaan Umum dan Perumahan Rakyat Kabupaten Lampung Barat".

\section{KAJIAN TEORI}

\section{Pengertian Pengembangan Sumber Daya Manusia}

CIDA (Canadian International Development Agency) seperti dikutip oleh Effendi (2013) mengemukakan bahwa pengembangan sumber daya manusia menekankan manusia baik sebagai alat (means) maupun sebagai tujuan akhir pembangunan. Dalam jangka pendek, dapat diartikan sebagai pengembangan pendidikan dan pelatihan untuk memenuhi segera tenaga ahli tehnik, kepemimpinan, tenaga administrasi.

Armstrong (2017) menyatakan sebagai berikut: "Pengembangan sumber daya manusia berkaitan dengan tersedianya kesempatan dan pengembangan belajar, membuat program-program training yang meliputi perencanaan, penyelenggaraan, dan evaluasi atas program-program tersebut". McLagan dan Suhadolnik (Wilson, 2017) mengatakan: "HRD is the integrated use of training and development, career development, and organisation development to improve individual and organisational effectiveness". (Terjemahan bebas: Pengembangan SDM adalah pemanfaatan pelatihan dan pengembangan, pengembangan karir, dan pengembangan 
organisasi, yang terintegrasi antara satu dengan yang lain, untuk meningkatkan efektivitas individual dan organisasi).

Dari beberapa pengertian tersebut dapat dikatakan bahwa pengembangan sdm adalah segala aktivitas yang dilakukan oleh organisasi dalam memfasilitasi pegawai agar memiliki pengetahuan, keahlian, dan/atau sikap yang dibutuhkan dalam menangani pekerjaan saat ini atau yang akan datang. aktivitas yang dimaksud, tidak hanya pada aspek pendidikan dan pelatihan saja, akan tetapi menyangkut aspek karir dan pengembangan organisasi. Dengan kata lain, PSDM berkaitan erat dengan upaya meningkatkan pengetahuan, kemampuan dan/atau sikap anggota organisasi serta penyediaan jalur karir yang didukung oleh fleksibilitas organisasi dalam mencapai tujuan organisasi.

\section{Prestasi kerja Pegawai}

Prestasi merupakan kemampuan untuk memilih tujuan yang tepat atau peralatan yang tepat untuk pencapaian tujuan yang ditetapkan (Handoko, 2017). Sedangkan menurut Devung prestasi adalah tingkat kemampuan untuk mencapai tujuan dengan tepat dan baik (Devung, 2017). Menurut kamus Administrasi perkantoran prestasi berasal dari kata efektif yang berarti terjadinya suatu efek yang dikehendaki dalam suatu perbuatan (2011). Kerja menurut The Liang Gie adalah keseluruhan pelaksanan aktivias jasmaniah dan rohaniah yang dilakukan manusia untuk mencapai tujuan tertentu berhubungan dengan kelangsungan hidupnya (Liang Gie, 2011).

Pendapat lain mengatakan bahwa prestasi kerja berarti penyelesaian pekerjaan tepat pada waktunya seperti yang telah ditetapkan sebelumnya (Siagian, 2016). Dari pendapat diatas dapat disimpulkan bahwa prestasi kerja adalah suatu keadaan yang menunjukkan hasil atau akibat seperti yang dikehendaki dan sesuai dengan waktu yang telah ditetapkan.

\section{Faktor-faktor yang mempengaruhi prestasi kerja}

Menurut Richard dan M. Steers (2010) faktor-faktor yang mempengaruhi tercapainya prestasi kerja yaitu :

1. Karakteristik Organisasi

Karakteristik organisasi terdiri dari struktur dan teknologi organisasi. Struktur merupakan hubungan yang relatif tetap sifatnya, struktur merupakan cara untuk suatu organisasi menyusun orang-orangnya untuk menciptakan sabuah organisasi yang meliputi jumlah spesialisasi pekerjaan, desentralisasi pengendalian untuk penyelesaian pekerjaan. Sedangkan teknologi merupakan suatu organisasi untuk mengubah masukan mentah menjadi keluaran jadi.

\section{Karakteristik Lingkungan}

Lingkungan mencakup dua aspek yang berhubungan yaitu lingkungan intern dan ekstern. Lingkungan intern dikenal dengan iklim organisasi yang meliputi atribut lingkungan kerja seperti kepuasan dan prestasi. Lingkungan ekstern menyangkut semua kekuatan yang timbul diluar batas organisasi yang mempengaruhi tindakan dalam organisasi seperti adanya peraturan pemerintah.

\section{Karakteristik Pekerja}

Pekerja mempunyai pandangan, tujuan, kebutuhan dan kemampuan yang berbeda-beda sehingga akan menyebabkan perbedaan perilaku antara orang satu denga orang lain. Prestasi merupakan modal utama didalam organisasi yang akan berpengaruh besar terhadap prestasi, sebab meskipun teknologi yang dipergunakan canggih jika tanpa prestasi tidak ada gunanya. 
4. Kebijakan dan praktek manajemen

Manajer/ pimpinan memegang peranan sentral dalam keberhasilan suatu organisasi melalui perencanaan, koordinasi dan memperlancar kegiatan yang ditujukan pada sasaran. Sehingga manajer mempunyai kewajiban untuk menjamin bahwa struktur organisasi konsisten dan menguntungkan untuk teknologi dan lingkungan yang ada. Selain itu manajer juga bertanggungjawab untuk menetapkan suatu sistem imbalan yang pantas sehingga dapat memuaskan kebutuhan pekerja dan tujuan pribadinya dalam mengejar sasaran organisasi.

\section{METODE PENELITIAN}

\section{Objek Penelitian}

Objek Penelitian dalam penelitian ini adalah pegawai Dinas Pekerjaan Umum dan Perumahan Rakyat Kabupaten Lampung Barat. Penelitian dilaksanakan pada rentang waktu April 2017 hingga Mei 2017.

\section{Metode dan Teknik Pengumpulan Data}

Dalam penelitian ini jenis data yang diperlakukan adalah :

\section{a. Data Primer}

Data primer merupakan data dasar yang akan diperoleh langsung tanpa perantara orang atau lembaga lain sebagai pihak ketiga. Data primer ini diperoleh dengan wawancara melalui responden dengan menggunakan daftar pertanyaan.

\section{b. Data Sekunder}

Data skunder merupakan data yang diperoleh melalui orang lain yang berhubungan dengan permasalahan yang dipecahkan. Data sekunder ini diperoleh melalui cara studi dokumenter yaitu mengumpulkan dan mempelajari brosurbrosur serta dokumen organisasi.
Langkah-langkah pengumpulan data yang penulis lakukan dengan mengadakan penelitian lapangan yaitu Penelitian yang dilakukan pada Kantor Dinas Pekerjaan Umum dan Perumahan Rakyat Kabupaten Lampung Barat, adapun teknik yang digunakan dalam pengumpulan data adalah dengan :

1. Observasi, yaitu mengadakan survey atau pengamatan langsung kelokasi penelitian.

2. Interview atau wawancara, yaitu mengadakan tanya jawab langsung dengan pegawai pada Kantor Dinas Pekerjaan Umum dan Perumahan Rakyat Kabupaten Lampung Barat.

3. Dokumentasi, yaitu mengumpulkan dan mencatat dokumentasi yang relevan.

4. Quisioner, yaitu membuat pertanyaan yang berhubungan dengan varibael penelitian.

\section{Sampel dan Populasi}

Menurut Suharsimi Arikunto (2012) apabila objek penelitian kurang dari 100 maka lebih baik diambil semua, selanjutnya jika jumlah lebih dari 100 maka dapat diambil antara $10-15$ persen . Diketahui jumlah pegawai berjumlah 40 orang, sehingga responden dalam penelitian ini berjumlah 40 orang. Kriteria Umum untuk skor yang dipergunakan daftar pertanyaan dalam penelitian ini adalah skala likert dengan skoring bernila 1,2,3,4,5 untuk jawaban pada setiap item pertanyaan .

\section{Metode Analisis Data}

Untuk pengolahan data dalam bentuk tabulasi hasil jawaban responden kemudian dilakukan analisis data melalui metode analisis secara kualitatif dan analisa kuantitatif.

Analisis kualitatif merupakan analisis yang dinyatakan dalam bentuk uraian dan didasarkan pada data yang telah ada. Data 
kualitatif merupakan data berupa informasi yang kemudian dikaitkan dengan data lainnya sehingga memunculkan suatu kebenaran. Analisis ini berguna untuk menjelaskan tentang berbagai macam masalah atau hal-hal penting yang dinyatakan dalam bentuk kalimat.

Analisis kuantitatif yang dilakukan berdasarkan data primer yang diperoleh dari penyebaran instrument (daftar pertanyaan) kepada sampel, dan untuk mengetahui pengaruh dari variabel bebas (independent variable) terhadap variabel terikat (dependent variable).

Persamaan Regresi Linear Sederhana menentukan persamaan regresi linear sederhana untuk X :

$$
Y=a+b X+e
$$

Keterangan:

$$
\begin{aligned}
& \mathrm{Y}=\text { Prestasi Kerja } \\
& \mathrm{a}=\text { Konstanta } \\
& \mathrm{b}=\text { Koefisien regresi } \mathrm{X} \\
& \mathrm{X}=\text { Pengembangan SDM } \\
& \mathrm{e}=\text { Faktor kesalahan }
\end{aligned}
$$

Untuk mengetahui besarnya pengaruh, penghitungan koefisien korelasi tersebut kemudian dilanjutkan dengan Rumus Koefisien Determinasi atau Koefisien Penentu (KP):

$$
K P=(r)^{2} x 100 \%
$$

Untuk menguji secara hipotesis secara parsial digunakan Uji t dengan rumus :

$$
t_{\text {hitung }}=\frac{r \sqrt{N-2}}{\sqrt{1-r^{2}}}
$$

Keterangan:

$$
\begin{array}{ll}
\mathrm{t}_{\text {hitung }} & =\text { Nilai } \mathrm{t} \\
\mathrm{r} & =\text { Koefisien Korelasi } \\
\mathrm{N} & =\text { Jumlah responden }
\end{array}
$$

Kriteria untuk Uji $\mathrm{t}$ adalah sebagai berikut :

a) Jika $t_{\text {hitung }}>t_{\text {tabel }}$ maka Ha diterima dan Ho ditolak.

b) Jika $t_{\text {hitung }} \leq t_{\text {tabel }}$ maka Ha ditolak dan Ho diterima.

Taraf signifikan dalam penelitian ini digunakan $\alpha=0,05$ atau 5\%. Yang dimaksud dengan Hipotesis nol (Ho) dan Hipotesis alternatif $(\mathrm{Ha})$ adalah :

Ho $=r \leq 0=$ Berarti tidak ada pengaruh pengembangan SDM terhadap prestasi kerja

$\mathrm{Ha}=\mathrm{r}>0=$ Berarti ada pengaruh pengembangan SDM terhadap prestasi kerja (Sugiyono, 2008).

\section{HASIL DAN PEMBAHASAN}

Data penelitian yang telah dikumpulkan kemudian diolah untuk menguji kualitas data berupa uji validitas dan reliabilitas menunjukkan bahwa koefisien korelasi pearson moment untuk setiap item butir pertanyaan dengan skor total variabel pengembangan SDM (X), dan prestasi kerja (Y) signifikan pada tingkat signifikan $\alpha 0,05$. Dengan demikian dapat diinterprestasikan bahwa setiap item indikator instrumen masing-masing variabel tersebut valid. Artinya item-item yang tersaji dalam kuisioner benar-benar mampu mengungkapkan dengan pasti apa yang akan diteliti.

\section{Uji Validitas}

Pengujian validitas faktor terhadap pertanyaan variabel $\mathrm{X}$, dan $\mathrm{Y}$ dilakukan dengan membandingkan nilai $\mathrm{r}_{\text {hitung }}$ dengan nilai $\mathrm{r}_{\text {tabel }}$ pada tingkat kepercayaan $95 \%$. Kriteria Uji :

- Apabila $r_{\text {hitung }}>r_{\text {tabel }}$ maka pertanyaan valid dan dapat dipergunakan sebagai intrumen penelitian selanjutnya. 
- Apabila $\mathrm{r}_{\text {hitung }}<\mathrm{r}_{\text {tabel }}$ tabel maka pertanyaan tidak valid dan tidak dapat dipergunakan sebagai intrumen penelitian selanjutnya.

Hasil perhitungan diatas menunjukkan nilai $\mathrm{rX}=0,830$, dan $\mathrm{rY}=0,897$. Pada tingkat kepercayaan $95 \%$ dan $\mathrm{n}=20$, diperoleh nilai $r$ tabel sebesar 0,632. Karena seluruh nilai korelasi product moment $\mathrm{rX}=0,830$, dan $\mathrm{rY}=0,897$ lebih besar dibandingkan $r_{\text {tabel }}$ 0,632, maka seluruh faktor pertnyaan valid dan dapat digunakan sebagai instrumen penelitian selanjutnya.

\section{Uji Reliabilitas Data}

Suatu instrumen pengukuran dikatakan reliabel jika pengukurannya konsisten dan cermat akurat. Jadi uji reliabilitas instrumen dilakukan dengan tujuan untuk mengetahui konsistensi dari instrumen sebagai alat ukur, sehingga hasil suatu pengukuran dapat dipercaya.Formula yang digunakan untuk menguji reliabilitas instrumen dalam penelitian ini adalah Koefisien Alfa (á) dari Cronbach. Selanjutnya penarikan kesimpulan dengan cara membandingkan nilai $\alpha$ dengan nilai acuan sebesar 0,600 . Kriterianya jika nilai hitung $\alpha$ lebih besar $(<)$ dari 0,600, maka item instrumen dinyatakan reliabel.

\section{Analisis Kuantitatif}

Berdasarkan hubungan korelasi antara pengembangan sumber daya manusia terhadap prestasi kerja sebesar 0,807 yang berada antara $\geq 0,70-<0,90$ terkategori kuat dan bersifat positif. Nilai $\mathrm{P}(\mathrm{Sig})=$ $0,000<\alpha=0,05$ menunjukkan hubungan yang terbentuk sedang dan signifikan, dengan demikian Ho ditolak dan $\mathrm{Ha}$ diterima. Nilai korelasi positif menunjukkan apabila pengembangan sumber daya manusia pegawai telah sesuai, maka prestasi kerja pegawai akan meningkat dan semakin baik. Hubungan korelasi antara deskripsi kerja terhadap prestasi kerja sebesar 0,916 yang terletak antara $\geq 0,90-1,00$ terkategori sangat kuat dan bersifat positif. Nilai $\mathrm{P}(\mathrm{Sig})=0,00<\alpha$ $=0,05$ menunjukkan hubungan yang terbentuk kuat dan signifikan, dengan demikian Ho ditolak dan $\mathrm{Ha}$ diterima. Nilai korelasi positif menandakan apabila deskripsi kerja semakin baik, maka prestasi kerja pegawai akan semakin baik pula.

Hasil $t_{\text {hitung }}$ variabel pengembangan sumber daya manusia (X) pada Tabel Coefficients sebesar 2,520 lebih besar dari nilai $t_{\text {tabel }}$ sebesar 1,717 , dan nilai signifikansi sebesar 0,019 yang lebih kecil dari 0,05 membuktikan variabel pengembangan sumber daya manusia $(X)$ secara parsial berpengaruh signifikan terhadap prestasi kerja pegawai (Y) pada Dinas Pekerjaan Umum dan Perumahan Rakyat Kabupaten Lampung Barat. Dengan demikian disimpulkan hipotesis Ho di tolak dan $\mathrm{H}_{1}$ di terima.

Secara parsial variabel bebas berpengaruh signifikan terhadap prestasi kerja pegawai (Y) pada Dinas Pekerjaan Umum dan Perumahan Rakyat Kabupaten Lampung Barat. Hal ini dibuktikan dari nilai thitung pada masing masing variabel lebih besar dari nilai $t_{\text {tabel }}$. Koefisien regresi positif pada seluruh variabel menunjukkan hubungan searah, dan apabila pengembangan sumber daya manusia telah sesuai, maka akan menimbulkan prestasi kerja yang semakin meningkat dan baik pula.

Nilai $\mathrm{R}$ sebesar 0,935 menunjukkan tingkat hubungan antara variabel pengembangan sumber daya manusia $(X)$ terhadap prestasi kerja pegawai (Y) pada Dinas Pekerjaan Umum dan Perumahan Rakyat Kabupaten Lampung Barat bersifat searah serta terkategori sedang, sedangkan nilai $\mathrm{R}^{2}$ sebesar 0,875 berarti kontribusi variabel pengembangan sumber daya 
manusia (X) mampu menjelaskan tingkat perubahan prestasi kerja pegawai (Y) sebesar $87,5 \%$, sedangkan sisanya $12,5 \%$ dijelaskan variabel lain diluar model.

\section{KESIMPULAN DAN SARAN}

\section{Kesimpulan}

Berdasarkan hasil penelitian dapat disimpulkan bahwa pengembangan sumber daya manusia (X) secara parsial berpengaruh positif dan signifikan terhadap prestasi kerja pegawai (Y). Hal ini dibuktikan dengan nilai $t_{\text {hitung }}=2,520(\mathrm{X})$ yang lebih besar dari nilai $t_{\text {tabel }}=1,717$, serta nilai signifikansi P (Sig) 0,019 lebih kecil dari $\alpha=0,05$, sehingga hipotesis Ho ditolak dan $\mathrm{H}_{1}, \mathrm{H}_{2}$ diterima, maka hipotesis yang diajukan yaitu terdapat pengaruh pengembangan sumber daya manusia terhadap peningkatan prestasi kerja pegawai Dinas Pekerjaan Umum dan Perumahan Rakyat Kabupaten Lampung Barat dapat diterima.

\section{Saran}

Adapun saran yang diajukan peneliti adalah sebagai berikut:

1. Dilaksanakannya langkah langkah perbaikan dari program pengembangan sumber daya manusia yang dilakukan sehingga langkah langkah pengembangan SDM yang selama ini belum memberikan dampak peningkatan prestasi kerja pegawai dapat disempurnakan. Langkah langkah perbaikan harus menggunakan nilai nilai terukur sehingga dapat diterima semua pihak.

2. Dilaksanakannya pengembangan kemampuan penguasaan teknologi, baik secara internal organisasi maupun eksternal organisasi sehingga penguasaan teknologi dapat merata untuk setiap pegawai.
3. Tumpang tindih pelaksanaan tugas dapat diatasi dengan koordinasi secara berkala dan pendalaman pemahaman deskripsi kerja sehingga organisasi dapat berjalan secara team work dan terintegral antar bidang/bagian.

4. Diberikannya reward untuk pegawai yang berprestasi serta pemberian sanksi bagi pegawai yang tidak mencapai target kerja sehingga menjadi dorongan tersendiri bagi pegawai untuk meningkatkan prestasi kerjanya.

\section{DAFTAR PUSTAKA}

Arikunto, Suharsimi. 2012. Prosedur penelitian. Jakarta: Rineka Cipta.

Chester I Bernard . 2010. The communication perspective (terjemahan). Jakarta: Elek Media Komputindo.

Edward H. Schein. 2012. Manajemen Sumber Daya Manusia Untuk Bisnis Kompetitif. Yogyakarta: Gajahmada University Press.

Griffin dan Ebert. 2011. Manajemen Personalia. Jakarta: Gramedia.

Handoko, T. Hani. 2017. Manajemen Personalia dan Manajemen Sumber Daya Manusia. Yogyakarta: BPFE.

Hicks dan gullet, 2016. Managing Cultural Differences. (terjemahan). Jakarta: Elek Media Komputindo.

Kurnianti, tjahjono, 2013.Manajemen Sumber Daya Manusia. Jakarta: Bumi Aksara.

Nawawi, Hadari. 2017. Manajemen Sumber Daya Manusia Untuk Bisnis Kompetitif. Yogyakarta: Gajahmada University Press. 
Nitiatmodjo, 2017. 2016. Organisasi. Bumi Aksara. Jakarta.

Poster. 2015. Manajemen Sumber Daya Manusia. Yogyakarta: Gajahmada University Press.

Robbins, Stephen P. 2011. Prilaku Organisasi Jilid I. Alih bahasa oleh Drs. Hadyana Pujuutmaka dan Drs. Benyamin Molan. Jakarta: Penerbit Prenhallindo.

Siagian. 2016. Dasar dasar Manajemen. Jakarta: Gramedia.

Sudjana. 2017. Metode Statistika. Bandung: Tarsito.

Simamora. 2015. Efektifitas kerja. Jakarta: Bumi Aksara.

S.Schuler \& E. Jakson. 2017. Manajemen SumberDaya Manusia Menghadapi Abad Ke-21. Jakarta: Erlangga.

Stogdill dan Coons. 2017 . Improving Organizational. Jakarta: Gramedia.

Sugiyono. 2008. Penelitian dan Statistik. Yogyakarta: Penerbit BPFE.UGM.

Taylor. 2010. Management thought. Jakarta: Gramedia.

USBRJ, 2011. Pedoman Penulisan Tesis. Program Pasca Sarjana USBRJ. Bandar Lampung

Wayne dan Awad, 2011. Managing organization, (terjemahan). Jakarta: PT.Gramedia Pustaka Umum. 